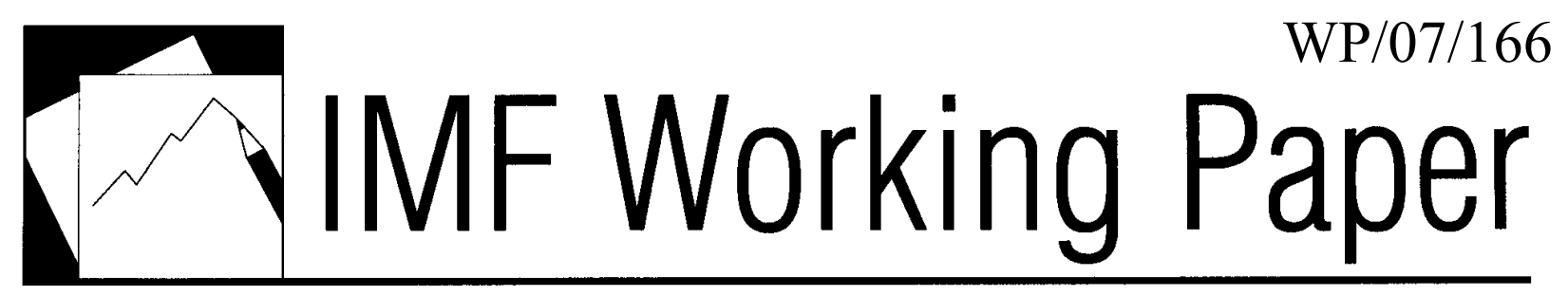

\title{
Real Effects of Common Currencies in East Asia
}

\author{
Kazuko Shirono
}





\section{IMF Working Paper}

IMF Institute

\section{Real Effects of Common Currencies in East Asia}

Prepared by Kazuko Shirono ${ }^{1}$

Authorized for distribution by Jorge Roldos

July 2007

\begin{tabular}{l} 
Abstract \\
\begin{tabular}{|l|} 
This Working Paper should not be reported as representing the views of the IMF. \\
The views expressed in this Working Paper are those of the author(s) and do not necessarily represent \\
those of the IMF or IMF policy. Working Papers describe research in progress by the author(s) and are \\
published to elicit comments and to further debate.
\end{tabular} \\
\hline
\end{tabular}

Since the 1997 Asian currency crisis, new interest has emerged in the formation of a common currency area in East Asia. This paper provides estimates of trade and welfare effects of East Asian currency unions, using a micro-founded gravity model. Counter-factual experiments to assess the effects of various hypothetical currency arrangements for East Asia suggest that an East Asian currency union will double bilateral trade in the region, but the resulting welfare effects will be moderate. However, if Japan, a major trade partner for East Asia, is included in the union, welfare effects increase substantially. The evidence thus suggests that certain regional currency arrangements in East Asia will stimulate regional trade rigorously and can generate economically significant welfare gains.

JEL Classification Numbers: F10, F15

Keywords: Currency Union; East Asia; Gravity Model

Author's E-Mail Address: kshirono@,imf.org

\footnotetext{
${ }^{1}$ I wish to thank Shigeru Iwata, Yuko Kinoshita, Ling Hui Tan, Jorge Roldos and seminar participants at the IMF Institute for useful comments and suggestions.
} 


\section{Contents}

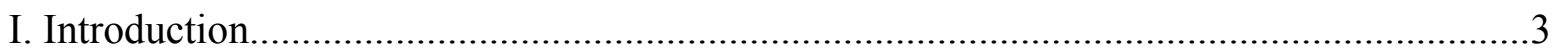

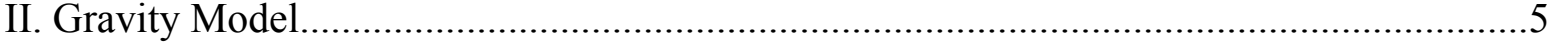

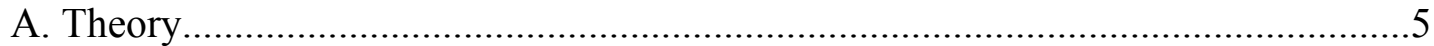

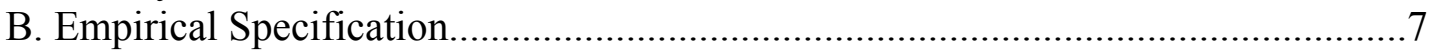

III. National Currencies as a Trade Barrier................................................................. 8

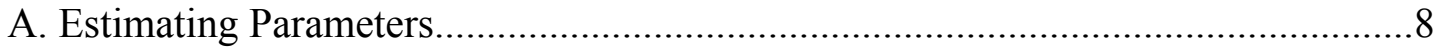

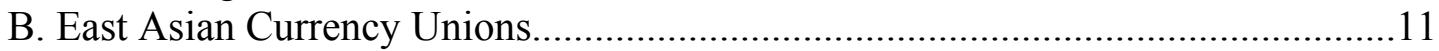

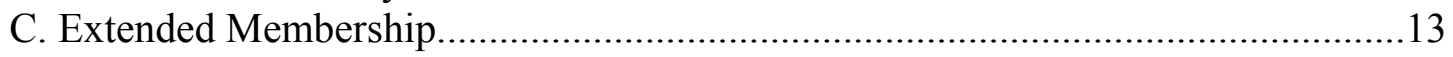

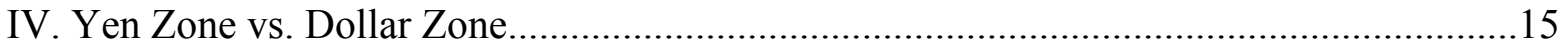

A. Exchange Rate Policy in East Asia............................................................. 15

B. Common Currency Arrangements.............................................................. 16

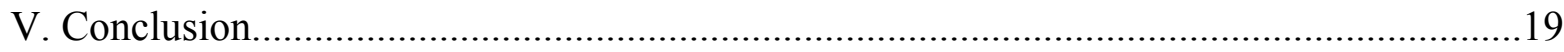

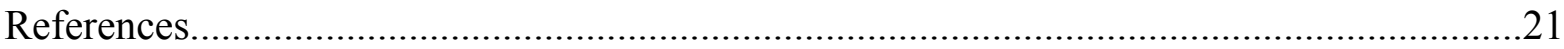

Tables

1. Gravity Model Estimation Results...................................................................

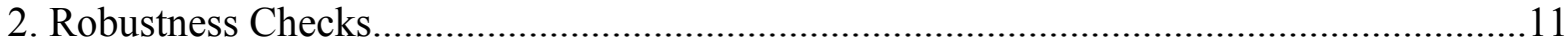

3. Common Currency Arrangements in East Asia...........................................................12

4. Common Currency Arrangements with Australia and New Zealand...............................14

5. Unilateral Arrangements vs. Regional Arrangements............................................. 17

Figures

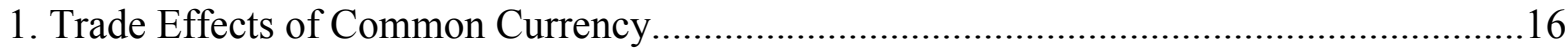

2. Welfare Effects of Common Currency.........................................................................18 


\section{INTRODUCTION}

The East Asian currency crisis of 1997 has revealed vulnerabilities of the exchange rate regime in the region. Before the crisis, East Asia was known as a soft dollar zone in which countries loosely pegged their currencies to US dollar (Frankel (1993) and Frankel and Wei (1994)).Various studies have shown that this de facto dollar peg was one of the main causes of the crisis, and many researchers have advocated alternative exchange rate arrangements to enhance exchange rate stability in East Asia. For example, Williamson (1999) proposes a common basket peg among East Asian economies. ${ }^{2}$ Ogawa and Ito (2002) also advocate a basket peg to keep the real effective exchange rate stable. Kwan (1998) makes a proposal for a formation of a yen bloc in East Asia. On the other hand, McKinnon (2000a) proposes to restore the dollar-based exchange rate regime in East Asia while strengthening bank regulations.

Among these recommendations, the boldest is a formation of a common currency area in East Asia, and many policy makers have expressed interests in the idea. For example, the Association of Southeast Asian Nations (ASEAN) issued the Hanoi Plan of Action in 1998 and indicated to conduct studies on the feasibility of establishing a common currency in the region. ${ }^{3}$ On the other hand, the Asian Development Bank has organized a seminar on a single currency for East Asia, and Haruhiko Kuroda, Special Adviser to the Cabinet of Japan at the time, has argued that the East Asian economies are so well integrated, and this high degree of regional integration calls for "intra-region exchange rate stabilization and ultimately a single currency in East Asia." "4 More recently, finance ministers from China, Japan and Korea have announced tentative measures to coordinate their currencies in manners that can ultimately lead to the creation of a common regional currency. ${ }^{5}$

What is the economic impact of a common currency on East Asian countries? Despite various policy discussions on the issue, surprisingly little is known about the actual benefits of a single currency in East Asia. A standard analysis of a currency union usually employs the theory of optimum currency areas (OCA). The OCA theory lists key conditions required to form a successful currency union in a region. Various studies have applied OCA criterion to East Asia. However, the existing studies have often yielded conflicting results. For

\footnotetext{
${ }^{2}$ See also Williamson (2000).

${ }^{3}$ The Hanoi Plan of Action includes a series of plans aimed at facilitating further regional integration. For more on this, see ASEAN Secretariat (1999). See also the statement by Rodolfo C. Severino, Secretary-General of the ASEAN at the time, found at http://www.aseansec.org/3444.htm.

${ }^{4}$ See Kuroda (2004).

5 “Asian Finance Ministers Seek Common Currency,” New York Times, May 5, 2006, http:// www.nytimes.com.
} 
example, Eichengreen and Bayoumi (1999) find that based on OCA grounds, East Asian countries are as plausible candidates for a currency union as European Union countries. On other hand, Chow and Kim (2003) report that Asian countries face asymmetric shocks, and thus a common currency will be costly for East Asia. Lee and Barro (2006) also conduct the OCA analysis for East Asia and conclude that it is unclear whether East Asia is an optimum currency area. However, their calibration exercise shows that a currency union consisting of a broad group of East Asian economies will generate a net welfare gain for most member countries.

Instead of following the OCA literature, this paper focuses exclusively on the international trade aspect of currency unions and estimates the real benefits of a common currency in East Asia. In particular, this paper builds on recent development in the empirical trade literature and addresses the following questions:

1. Does a single currency in East Asia facilitate international trade among member countries? 2. How does a currency union in East Asia affect the welfare of member countries?

An undisputable benefit of a currency union is that it lowers trade costs associated with the use of national currencies and thus facilitates trade among member countries. This paper provides estimates of trade-creating effects and accompanying welfare gains of a single currency in East Asia, focusing on the eight East Asian economies: Hong Kong S.A.R., Singapore, Korea, Indonesia, Malaysia, Thailand, Philippines, and China. To this end, I estimate a rigorously micro-founded gravity equation that emerges from a general equilibrium trade model, using the theoretical approach of Anderson and van Wincoop (2001). One of the advantages of adopting a theory-based gravity equation is that once parameters are estimated, one can use the general equilibrium model to conduct comparative statics exercises. In particular, the model allows for counter factual experiments such as asking what the effects on trade and welfare are of a hypothetical currency union.

The estimates suggest that a regional currency union involving only East Asian countries will double bilateral trade among the members, but the resulting welfare effects are moderate. On the other hand, including Japan in the union enhances welfare effects significantly. Such a currency union will increase the welfare of member countries by 5.2 percent. Moreover, welfare gains are larger from a currency union with Japan than a union with the United States. Thus if East Asia is to form a regional currency union, Japanese membership is more important than the US membership. The empirical results also indicate that Japan plays a more significant role in the East Asian currency union than other industrialized neighbor countries in the region such as Australia and New Zealand. In sum, the evidence suggests that certain regional currency arrangements are beneficial for East Asia, and the role of Japan in such arrangements appears to have great importance to generate larger welfare gains.

The rest of the paper is organized as follows. The next section presents a theoretically grounded gravity equation. Section 3 reports estimation results of the gravity equation and conducts counter factual experiments to assess the impact of various common currency arrangements in East Asia. Section 4 compares the role of Japan and the United States in East Asian currency unions. Section 5 concludes. 


\section{Gravity Model}

\section{A. Theory}

This paper adopts a rigorously micro-founded gravity equation derived from a general equilibrium trade model. Many studies have estimated gravity equations to quantify the impact of various trade costs on bilateral trade flows. However, standard gravity equations typically have arbitrary specifications that have no theoretical ground. For this reason, ad-hoc gravity equations cannot be used to conduct comparative statics exercises, such as examining the effects of removing certain trade barriers on trade. On the other hand, a theoretically founded gravity equation has at least three advantages. First, once parameters are estimated, one can conduct comparative statics exercises by solving the general equilibrium model before and after changes in trade barriers. In particular, the model allows for counter-factual experiments of hypothetical scenarios about trade costs. Second, one can measure the welfare effects of removing trade barriers because the model generates an explicit welfare metric. Finally, since the model is exactly specified, specification errors will be limited.

I adopt the theoretical approach of Anderson and van Wincoop (2003) to obtain a microfounded gravity equation. ${ }^{6}$ The Anderson-van Wincoop model builds upon two building blocks: First, each country has the endowment $\bar{y}_{j}$ units of a good and specializes in the production of the good. Thus all goods are differentiated by place of production. Second, preferences are expressed as an identical constant elasticity of substitution (CES) utility function. Letting $c_{i j}$ denote consumption of country $j$ consumers of goods from country $i$, the utility function of country $j$ is expressed as

$$
U_{j}=\left(\sum_{i} \beta_{i}^{(1-\sigma) / \sigma} c_{i j}^{(\sigma-1) / \sigma}\right)^{\sigma /(\sigma-1)}
$$

where $\sigma$ is the elasticity of substitution between goods, and $\beta_{i}$ is a positive parameter that measures the weight placed on the good from country $i$. The budget constraint for country $j$ is given by

$$
\sum_{i} p_{i j} c_{i j}=y_{j}
$$

where $y_{j}$ is the nominal income of country $j$, and $p_{i j}$ is the country $j$ import price of goods from country $i$. Prices vary across countries because of trade costs. Letting $p_{i}$ denote the exporter's price, the difference between the importer price and exporter price is matched by the bilateral trade cost factor $t_{i j}$. Thus $p_{i j}=p_{i} t_{i j}$. Since the output is given as an endowment, the nominal income of country $j$ is expressed as $y_{j}=p_{j} \bar{y}_{j}$.

\footnotetext{
${ }^{6}$ There are other models that generate a gravity equation. For example, Eaton and Kortum (2001) derive a gravity equation using a Ricardian model.
} 
Imposing market clearing conditions upon the above structure, Anderson and van Wincoop derive the following gravity equation:

$$
x_{i j}=\frac{y_{i} y_{j}}{y^{w}}\left(\frac{t_{i j}}{P_{i} P_{j}}\right)^{1-\sigma}
$$

where $x_{i j}$ is nominal demand of country $j$ for goods from country $i, y^{w}$ is the nominal value of the world output, and $P_{j}$ and $P_{i}$ are CES price indices given by

$$
P_{j}=\left[\sum_{i}\left(\beta_{i} p_{i} t_{i j}\right)^{1-\sigma}\right]^{1 /(1-\sigma)}
$$

After imposing market clearing conditions, these price indices are subject to

$$
P_{j}^{1-\sigma}=\sum_{i} \frac{y_{i}}{y^{w}}\left(\frac{t_{i j}}{P_{i}}\right)^{1-\sigma} \quad \forall j
$$

$P_{j}$ is called "multilateral trade resistance" because it summarizes the trade costs between country $j$ and all of its trading partners. The above gravity equation thus says that, after controlling for size, bilateral trade depends on the bilateral trade barrier between $j$ and $i$, relative to the product of the multilateral trade resistance terms.

The model also provides a welfare metric that allows one to measure welfare effects of changes in trade barriers. ${ }^{7}$ The indirect utility function is expressed as

$$
U_{j}=\frac{y_{j}}{P_{j}}
$$

Thus the welfare is inversely related to the multilateral resistance index. The intuition behind this is straightforward: The price index becomes smaller as certain trade barriers are removed, and savings on trade costs generate welfare gains because fewer resources are wasted on trade costs.

It is instructive to discuss some of the key implications of the model before moving to the empirical specification. This will facilitate the interpretation of the results from various policy experiments conducted below.

\footnotetext{
7 Thus the "welfare effect" of a currency union in this paper is very specific. It refers to a change in welfare generated by a change in trade barriers, namely, a reduction in trade costs due to forming a currency union. Other potential welfare gains from a common currency are not captured here.
} 
First, the model implies that the increase in trade among the members of a currency union is smaller the larger the size of the union. On the other hand, the welfare effect of a currency union is larger the bigger the size of the union. This is because the average trade barrier, namely, the multilateral trade resistance term for the member countries of a currency union, declines more after forming a union the larger the size of the union. As a result, relative trade barriers between those union members will decline less the larger the size of the union, thereby yielding smaller increase in trade within the union. On the other hand, the larger drop in the multilateral resistance index generates a greater increase in welfare since the welfare is inversely related to the multilateral resistance term. Thus a currency union consisting of the entire East Asia is likely to generate a smaller increase in trade and a larger increase in welfare than a currency union consisting of a subset of East Asian countries.

Second, an increase in trade among the members of a currency union is smaller the higher the initial level of trade among its members before forming the union. On the other hand, the welfare effect of a currency union is larger the higher the level of pre-union trade. This is because the average trade barrier drops more after forming a union the higher the level of pre-union trade. Thus the magnitude of trade and welfare effects of a currency union also depends on the initial level of regional integration in trade among union members.

\section{B. Empirical Specification}

Equation (3) shown above is the basic gravity equation. For estimation purposes, I divide equation (3) by $y_{i} y_{j}$ and take logs to obtain:

$$
\ln \left(\frac{x_{i j}}{y_{i} y_{j}}\right)=-\ln y^{w}+(1-\sigma) \ln t_{i j}-(1-\sigma) \ln P_{i}-(1-\sigma) \ln P_{j}
$$

Note that $t_{i j}, P_{i}$ and $P_{j}$ are unobservable. I use country specific dummies to control for $P_{i}$ and $P_{j}$ to obtain consistent estimates by OLS. This approach is standard in the literature. ${ }^{8}$ Bilateral trade barriers $t_{i j}$ are measured by a set of observable variables. The gravity model itself does not say anything about specifications of bilateral trade barriers. I assume that trade barriers are expressed as a linear combination of various trade cost variables. ${ }^{9}$ In particular, assuming that

$$
t_{i j}=\left(d_{i j}\right)^{\rho} m^{\left(1-\delta_{i j}\right)} \prod_{k=1}^{K} \gamma_{k}^{z_{i j}^{k}}
$$

and taking logs of the above expression yields

\footnotetext{
${ }^{8}$ See, for example, Rose and van Wincoop (2001) and Eaton and Kortum (2002).

${ }^{9}$ This is also a standard assumption. Anderson and van Wincoop (2003) and Noguer and Siscart (2004), among others, use similar specifications.
} 


$$
\ln t_{i j}=\rho \ln d_{i j}+\left(1-\delta_{i j}\right) \ln m+\sum_{k=1}^{K} z_{i j}^{k} \ln \gamma_{k}+v_{i j}
$$

where $d_{i j}$ is bilateral distance, $m$ is the cost associated with national currencies, and $\delta_{i j}$ is a currency union dummy variable that equals 1 if country $i$ and $j$ belong to a currency union and zero otherwise. $z_{i j}^{k}$ is a control variable that captures other trade costs. $v_{i j}$ is the error term. Substituting equation (9) into equation (6), the estimation equation becomes:

$$
\ln \left(\frac{x_{i j}}{y_{i} y_{j}}\right)=\beta_{0}+\beta_{1} \ln d_{i j}+\beta_{2} \delta_{i j}+\sum_{k=1}^{K} \lambda_{k} z_{i j}^{k}-(1-\sigma) \ln P_{i}-(1-\sigma) \ln P_{j}+\varepsilon_{i j}
$$

where $\beta_{0}=(1-\sigma) \ln m-\ln y^{W}, \beta_{1}=(1-\sigma) \rho, \beta_{2}=(1-\sigma) \ln m$, and $\lambda_{k}=(1-\sigma) \ln \gamma_{k}$.

The coefficient of interest is $\beta_{2}$, and it is often interpreted as the effect of a common currency on bilateral trade. However, there are potentially two factors that can bias the estimate of $\beta_{2}$. First, price indices $P_{i}$ and $P_{j}$ also depend on trade costs, so ignoring these terms, which often happens in ad hoc gravity models, will cause an omitted variable problem. One way to solve this problem is to include country specific dummies in the regression to control for price index terms as discussed above. Second, even after correcting for omitted variable biases, one still needs to solve a general equilibrium model before and after forming a currency union in order to obtain correct estimates of the effects of a common currency on bilateral trade. This paper thus estimates equation (10) to obtain parameters of the model and conducts comparative statics exercises to examine the effects of a common currency in East Asia.

\section{National Currencies as a Trade Barrier}

\section{A. Estimating Parameters}

In this section, I evaluate the impact of introducing a common currency in East Asia on the bilateral trade flows and welfare for member countries. To this end, the gravity equation (10) is first estimated to obtain parameters of the model. Then I conduct counter-factual experiments using the general equilibrium model to assess the trade and welfare effects of various hypothetical common currency arrangements in East Asia.

The data set covers bilateral trade among 137 countries for the years 1980 and 1990. Bilateral trade is measured as the sum of nominal exports and imports deflated by the US price index and divided by two. Distance is calculated as great-circle distance using the information on the latitude and longitude of capital cities. The currency union variable $\delta_{i j}$ is equal to one either if a pair of trading countries belongs to a multilateral currency union or if one of the 
pair does not issue its own currency but instead uses the national currency of its partner (e.g. dollarization). The basic data are downloaded from Andrew Rose's website. ${ }^{10}$

Control variables of other trade costs $z_{i j}^{k}$ include (i) a common language dummy, which is one if a pair of countries uses the same languages and zero otherwise; (ii) a adjacency dummy, which is one if a pair of countries shares a border and zero otherwise; (iii) a political union dummy, which is one if a pair of countries belongs to a political union and zero otherwise; (iv) a colony-colonizer dummy, which is one if a pair of countries historically had a colony-colonizer relationship and zero otherwise; (v) a common colonizer dummy, which is one if a pair of countries had a common colonizer and zero otherwise; and (vi) a FTA dummy, which is one if a pair of countries belongs to a free trade area. These control variables are standard and widely used in other studies. ${ }^{11}$

Table 1: Gravity Model Estimation Results

\begin{tabular}{|c|c|c|c|c|}
\hline \multirow[b]{3}{*}{ Variable } & \multicolumn{4}{|c|}{ Regression } \\
\hline & $(1)$ & $(2)$ & (3) & (4) \\
\hline & & & & \\
\hline \multirow[t]{2}{*}{ Currency Union } & 1.03 & 0.91 & 1.04 & 0.91 \\
\hline & $(0.18)^{* * *}$ & $(0.18)^{* * *}$ & $(0.18)^{* * *}$ & $(0.17)^{* * *}$ \\
\hline \multirow[t]{2}{*}{ Log Distance } & -1.43 & -1.38 & -1.43 & -1.38 \\
\hline & $(0.02)^{* * *}$ & $(0.02)^{* * *}$ & $(0.02)^{* * *}$ & $(0.02)^{* * *}$ \\
\hline \multirow[t]{2}{*}{ Common Language } & 0.55 & 0.17 & 0.55 & 0.17 \\
\hline & $(0.05)^{* * *}$ & $(0.05)^{* * *}$ & $(0.05)^{* * *}$ & $(0.05)^{* * *}$ \\
\hline \multirow[t]{2}{*}{ Adjacency } & 0.19 & 0.06 & 0.19 & 0.05 \\
\hline & $(0.12)$ & $(0.12)$ & $(0.13)$ & $(0.12)$ \\
\hline \multirow[t]{2}{*}{ Political Union } & & 0.68 & & 0.60 \\
\hline & & $(0.35)^{*}$ & & $(0.33)^{*}$ \\
\hline \multirow[t]{2}{*}{ Ex-Colony/Colonizer } & & 1.34 & & 1.35 \\
\hline & & $(0.10)^{* * *}$ & & $(0.10)^{* * *}$ \\
\hline \multirow[t]{2}{*}{ Common Colonizer } & & 0.70 & & 0.70 \\
\hline & & $(0.06)^{* * *}$ & & $(0.06)^{* * *}$ \\
\hline \multirow[t]{2}{*}{ FTA } & & 0.31 & & 0.35 \\
\hline & & $(0.12) * * *$ & & $(0.12)^{* * *}$ \\
\hline Year dummy & Yes & Yes & - & - \\
\hline Country dummy & Yes & Yes & - & - \\
\hline Year-country dummy & - & - & Yes & Yes \\
\hline $\mathrm{R} 2$ & 0.51 & 0.53 & 0.53 & 0.54 \\
\hline No. Observations & 10553 & 10553 & 10553 & 10553 \\
\hline
\end{tabular}

${ }^{10}$ The web address is http://faculty.haas.berkeley.edu/arose/.

${ }^{11}$ See, for example, Rose and van Wincoop (2001) and Glick and Rose (2002). 
Table 1 reports estimation results of the gravity equation (10). The first two specifications include year dummy and country dummy variables. Country specific dummies are used to control for the multilateral trade resistance terms. Column (1) shows a positive and highly significant currency union effect with a coefficient of 1.03 and a standard error of 0.18 . Column (2) reports the estimation results with a complete set of controls. The currency union effect becomes somewhat smaller to 0.91 , but it is still statistically significant with a standard error of 0.18 .

Column (3) and (4) in Table 1 repeat the same estimation exercises except that these two specifications include year specific country dummies instead of separate year and country dummies. Year-country interaction dummies are included to control for possibly time-variant multilateral trade resistance terms. While this treatment causes little change in the estimation results compared to column (1) and (2), this specification is more general. I will thus use the estimated parameters from column (4) to estimate the average impact of a common currency on bilateral trade and welfare for East Asian economies. ${ }^{12}$

There are two issues regarding the estimate of common currency effects. First, as noted above, $\beta_{2}=0.91$ is usually interpreted that a common currency is associated with an increase in trade of almost 250 percent $\left(e^{0.91} \approx 2.48\right)$ holding other things constant. This is a very large effect. However, this estimate does not take account of general equilibrium effects and therefore contains computational biases. The general equilibrium model needs to be solved before and after introducing a common currency in East Asia to obtain correct estimates of the currency union effects for East Asian economies.

Second, the estimate of $\beta_{2}(=0.91)$ is comparable to the estimates of Rose and van Wincoop (2001) who estimate the effects of EMU on trade and welfare of the member countries. However, different samples yield somewhat smaller estimates of $\beta_{2}$. Table 2 reports some robustness checks for the estimates of $\beta_{2}$. This sensitivity analysis is not meant to be extensive. Rather, it is conducted to get some sense about the range of variability of the estimates. The following robustness checks are reported: (1) Only the data for 1980 are used; (2) Only the data for 1990 are used; (3) North-north trade is excluded from the sample; (4) Only developing countries are included in the sample; (5) Only similar size countries are included (by less than a factor of 5); and (6) Australia, France, New Zealand, United Kingdom, and United States are excluded from the sample. In Table 2, many estimates are smaller than 0.91. In particular, the smallest estimate is 0.57 , which indicates that a currency union will increase bilateral trade by 176 percent, holding other things constant. Glick and Rose (2002) conduct more thorough robustness checks for the estimates of currency union effects, and report that their fixed effects estimates lie in the range of $(.59, .80) .{ }^{13}$ It is thus

\footnotetext{
${ }^{12}$ Clark and others (2004) also use a similar specification with year-country interaction dummies in estimating their gravity equations.

${ }^{13}$ Rose (2000) also conducts numerous robustness checks of the estimates, but his estimates (typically larger than 1) are much larger than those reported in Glick and Rose (2002). See also Rose (2002) who reviews existing studies on the effect of a currency union on trade.
} 
important to bear in mind that there are more conservative estimates of $\beta_{2}$ in other studies and the estimates in this paper may somewhat overstate common currency effects on trade.

Table 2: Robustness Checks

\begin{tabular}{lccc}
\hline & $\mathrm{CU}$ & No. Obs. & $\mathrm{R} 2$ \\
\hline 1980 & 1.07 & 5180 & 0.48 \\
& $(0.22)^{* * *}$ & & \\
\hline 1990 & 0.73 & 5373 & 0.52 \\
& $(0.27)^{* * *}$ & & \\
\hline No North-North trade & 0.74 & 10091 & 0.55 \\
& $(0.17)^{* * *}$ & & \\
\hline Only developing countries & 0.56 & 5517 & 0.57 \\
& $(0.21)^{* *}$ & & \\
\hline Similar-size countries & 0.92 & 8589 & 0.55 \\
& $(0.19)^{* * *}$ & & \\
\hline No Australia, France, NZ, UK, and U & 0.90 & 9312 & 0.54 \\
& $(0.20)^{* * *}$ & & \\
\hline
\end{tabular}

Notes: This table summarizes the results of some robustness checks. Only the estimates of the currency union variable are reported. All specifications include all of the explanatory variables listed in Table 1 . The first two specifications also include country dummies, and all other specifications include year-country interaction terms. ${ }^{* * *}$ and $* *$ indicate that estimates are statistically significant at the 1 percent and 5 percent levels, respectively. Standard errors are in parenthesis.

\section{B. East Asian Currency Unions}

This subsection reports the estimates of the average percentage increases in trade flows and welfare for East Asian countries under different common currency arrangements. One of the key issues on the exchange rate regime in East Asia is how to achieve exchange rate stability within the region given large fluctuations in the yen-dollar exchange rate. This subsection considers regional currency arrangements, treating the exchange rate policies of the United States and Japan as exogenous.

For the rest of the paper, I will use the following grouping of East Asian economies:

NIES3: Hong Kong, Singapore, and Korea

ASEAN4: Thailand, Malaysia, Indonesia, and Philippines

ASEAN 5: ASEAN4 and Singapore

East Asia (EA): NIES3 and ASEAN4

This subsection first reports common currency effects on bilateral trade for different groups of East Asian countries. All the estimates are obtained by solving the general equilibrium model before and after introducing a common currency among a certain group of countries. More specifically, average percentage changes in trade are calculated by comparing the 
bilateral trade of country-pairs that do not share a common currency with the bilateral trade of the same country-pairs in the counterfactual environment where they share a common currency. To solve the model, two additional assumptions are made. First, a parameter value for $\sigma$ is needed to solve the general equilibrium model. However, $\sigma$ cannot be estimated from equation (10). Thus I assume that $\sigma=5$ according to recent studies that estimate the elasticity of substitution. ${ }^{14}$ Anderson and van Wincoop (2003) show that different values of $\sigma$ affect the general equilibrium solutions very little. Second, I incorporate the border effect estimated in Anderson and van Wincoop (2003) in addition to the various trade cost factors considered in the regression. In other words, Anderson and van Wincoop's estimate of the border effect is included in the calculation of total trade costs. ${ }^{15}$

As discussed earlier, the theory suggests that the higher the trade levels before a currency union and the larger the size of the union, the smaller its effect on trade and the larger its effect on welfare. Thus the smallest trade effects but the largest welfare effects are expected from a common currency involving all the East Asian countries, holding other things constant.

Table 3 : Common Currency Arrangements in East Asia

\begin{tabular}{lcc}
\hline & \multicolumn{2}{c}{ Percentage increase } \\
\cline { 2 - 3 } & Trade & Welfare \\
\hline EA+ China & 114 & 3.7 \\
EA & $(28)$ & $(1.0)$ \\
& 125 & 2.5 \\
NIES3 & $(33)$ & $(0.7)$ \\
& 150 & 0.1 \\
ASEAN4 & $(43)$ & $(0.02)$ \\
\multirow{2}{*}{ ASEAN5 } & 118 & 3.2 \\
& $(30)$ & $(1.0)$ \\
China + Hong Kong & 120 & 3.0 \\
& $(31)$ & $(0.9)$ \\
\end{tabular}

Note: Standard errors are in parenthesis.

Table 3 summarizes the results. Table 3 shows that a common currency area among all East Asian countries will increase bilateral trade by 114 percent. If China is excluded, the average percentage increase in bilateral trade becomes larger to 125 percent. In all scenarios in Table 3 , the trade-creating effects of a common currency are positive, large, and economically and

\footnotetext{
${ }^{14}$ For example, Hummels (2001).

${ }^{15}$ Rose and van Wincoop (2001) adopt the same approach.
} 
statistically significant. However, these effects are not as large as the simple prediction from the gravity equation of 250 percent. This demonstrates that taking account of multilateral resistance terms makes common currency effects substantially smaller.

The trade-creating effects of common currencies in East Asia seem much larger than those of EMU. Rose and van Wincoop (2001) report that EMU will increase bilateral trade among the eleven member countries by 58 percent. This is about half of the size of the trade-creating effects of the East Asian currency union. This difference in the magnitude of trade effects partly comes from the fact that the degree of intra-regional trade in East Asia is not as high as that in Europe. In addition, the size of the currency union in East Asia is smaller than that in Europe. This in turn suggests that the welfare effects of common currencies in East Asia are unlikely to be very large.

Table 3 confirms this point. It shows that the welfare effects of currency unions are small or moderate in East Asia. For example, a currency union among ASEAN5 will increase the welfare of the members by 3.0 percent on average. If all other countries are also included, a currency union will increase the welfare of the members by 3.7 percent. This is economically significant, but moderate in magnitude compared to the average welfare increase of 11 percent for EUM members reported by Rose and van Wincoop (2001).

In sum, the estimates suggest that a currency union in East Asia will increase regional trade significantly, but the welfare gains are likely to be moderate. The above results provide upper-bound estimates of currency union effects to the extent that the currency union parameter (namely, $\beta_{2}$ in equation (10)) is overestimated. In other words, trade effects and welfare effects in practice can be smaller that what is reported above. However, this by no means indicates that the East Asian countries should not form a currency union because as the level of regional trade rises, benefits from a currency union are likely to increase. ${ }^{16}$ Given the ongoing movements toward greater regional integration in East Asia, potentially larger gains can be generated from a common currency arrangement over time as East Asia becomes integrated further.

\section{Extended Membership}

This subsection extends the above experiments by including additional countries in the East Asian currency arrangements. First, I introduce Australia and New Zealand into the analysis. These two countries are not only located geographically close to some of the East Asian economies, but also have close trade ties with them. Thus it is interesting to see how adding these two will change the picture.

Rows 1-5 in Table 4 report the results. The trade-creating effects are still large, ranging from 100 percent to 129 percent. On the other hand, the welfare effects become economically more significant. For example, the average percentage increase in welfare due to a currency

\footnotetext{
${ }^{16}$ Frankel and Rose (1998).
} 
union among ASEAN 4, Australia, and New Zealand is 5.2 percent. A currency union among East Asia, China, Australia, and New Zealand will increase the welfare of the member countries by 5.0 percent. These welfare effects are more substantial than the previous results reported in Table 3.

Table 4: Common Currency Arrangements with Australia and New Zealand

\begin{tabular}{lcc}
\hline & \multicolumn{2}{c}{ Percentage increase } \\
\cline { 2 - 3 } EA + China + Australia + New Zealand & Trade & Welfare \\
EA + Australia + New Zealand & 102 & 5.0 \\
NIES3+Australia+New Zealand & $(24)$ & $(1.4)$ \\
& 110 & 4.1 \\
ASEAN4 + Australia + New Zealand & $(27)$ & $(1.2)$ \\
& 129 & 2.1 \\
ASEAN5 + Australia + New Zealand & $(35)$ & $(0.6)$ \\
& 100 & 5.2 \\
EA + China + Japan + Australia + New Zealand & $(24)$ & $(1.5)$ \\
& 104 & 4.8 \\
& $(25)$ & $(1.4)$ \\
\end{tabular}

Note: Standard errors are in parenthesis.

Next, I add Japan to the experiment. The last row of Table 4 includes Japan in the East Asian currency union in addition to Australia and New Zealand. So far, the Japanese exchange rate policy has been treated as given. On the other hand, Japanese policy makers and scholars have expressed a great interest in regional exchange rate arrangements that involve Japan in some ways. ${ }^{17}$ As will be further discussed in the next section, it is quite interesting to examine what impact Japan may have if Japan joins the common currency arrangement in East Asia. ${ }^{18}$ The experiment in Table 4 offers some insight into the issue.

After adding Japan to the extended currency union, the trade creating effects remain to be large (93 percent), and the welfare effects become even more substantial (6.2 percent). Thus a first look at including Japan in regional currency arrangements seems to suggest that Japanese membership in such an arrangement will increase trade within the region and enhance welfare of member countries significantly.

\footnotetext{
${ }^{17}$ See, for example, Ito (2004), Ogawa and Ito (2002), and Kuroda (2004).

18 The analysis here, however, does not specify whether Japan adopts a regional currency or East Asian economies adopt the Japanese yen. Benefits from these two different arrangements may be the same quantitatively, but they are likely to have different costs and seignorage implications.
} 
These results naturally raise a question of the role of the United States in regional currency arrangements because it is an equally important trade partner for East Asian economies. While it is unlikely that the United States will voluntarily form a currency union with East Asian economies, it is not entirely clear whether a currency union with Japan will necessarily generate higher welfare gains to the region than a union with the United States given the fact that East Asian currencies were once closely linked to US dollar rather than Japanese yen. Thus quantifying trade and welfare effects of a currency union with the United States allows for evaluating the relative importance of Japan in regional currency arrangements in East Asia. The next section further investigates this point.

\section{Yen Zone vs. Dollar Zone}

\section{A. Exchange Rate Policy in East Asia}

This section examines the impact of including Japan and the United States in East Asian currency unions. It is interesting to incorporate Japan and the United States into the analysis of common currencies for East Asia because there has been a debate on the role of yen and dollar in East Asia for more than a decade. Before the Asian crisis of 1997-98, East Asia was known as a loose dollar zone. Frankel (1993) and Frankel and Wei (1994) show that most East Asian countries loosely peg their currencies to U.S. dollar, and the role of Japanese yen is quite limited in East Asia. These findings raise a question why East Asian countries, who have close ties with Japan through international trade, foreign direct investment, and official development assistance (ODA), do not peg their currencies to the Japanese yen. Ohno and Shirono (1997) argue that a unilateral deviation from a dollar peg will destabilize the real effective exchange rate of the deviator, so there is no incentive for East Asian countries to deviate unilaterally from a dollar peg as long as the rest of the region maintains the dollar peg. Ogawa and Ito (2002) show that a basket peg is a Nash equilibrium for East Asia, but so is a dollar peg. Their model suggests a problem of coordination failures in the exchange rate policy for East Asia. McKinnon (2000b) argues that focusing only on trade shares understates the importance of the U.S. dollar for East Asia because trade shares do not reflect the prevalence of dollar invoicing of trade in East Asia. In sum, existing studies tend to suggest that unless there is a collective action among East Asian countries, it will be difficult to change the exchange rate regime in East Asia.

On the other hand, since the East Asian crisis, movements toward regional economic cooperation and integration have been accelerating in East Asia. For example, various FTAs have been proposed and negotiated in the region. In the area of financial cooperation, the creation of an Asian Bond market has been considered among policy makers. ${ }^{19}$ Thus I shall revisit the debate on the role of yen and dollar in East Asia and compare the economic benefits of forming a currency union with Japan and with the United States.

\footnotetext{
${ }^{19}$ See Ito (2004) for an overview of recent movements toward economic integration in East Asia.
} 


\section{B. Common Currency Arrangements}

This subsection examines the impact of East Asian common currency arrangements that involve Japan and the United States. So far, it has been implicitly assumed that some form of regional currency arrangements (i.e., collective action by East Asian countries) is more desirable than unilateral arrangements in which individual countries pursue their own policy (i.e., no collective action). While a number of economists have argued for the benefits of regional exchange rate arrangements in East Asia, actual benefits of regional cooperation relative to unilateral policy are yet to be known. This subsection first considers common currency arrangements that remove bilateral exchange rate instability of East Asian currencies vis-à-vis Japanese yen or US dollar, and compares welfare gains from such unilateral arrangements to those from regional currency unions.

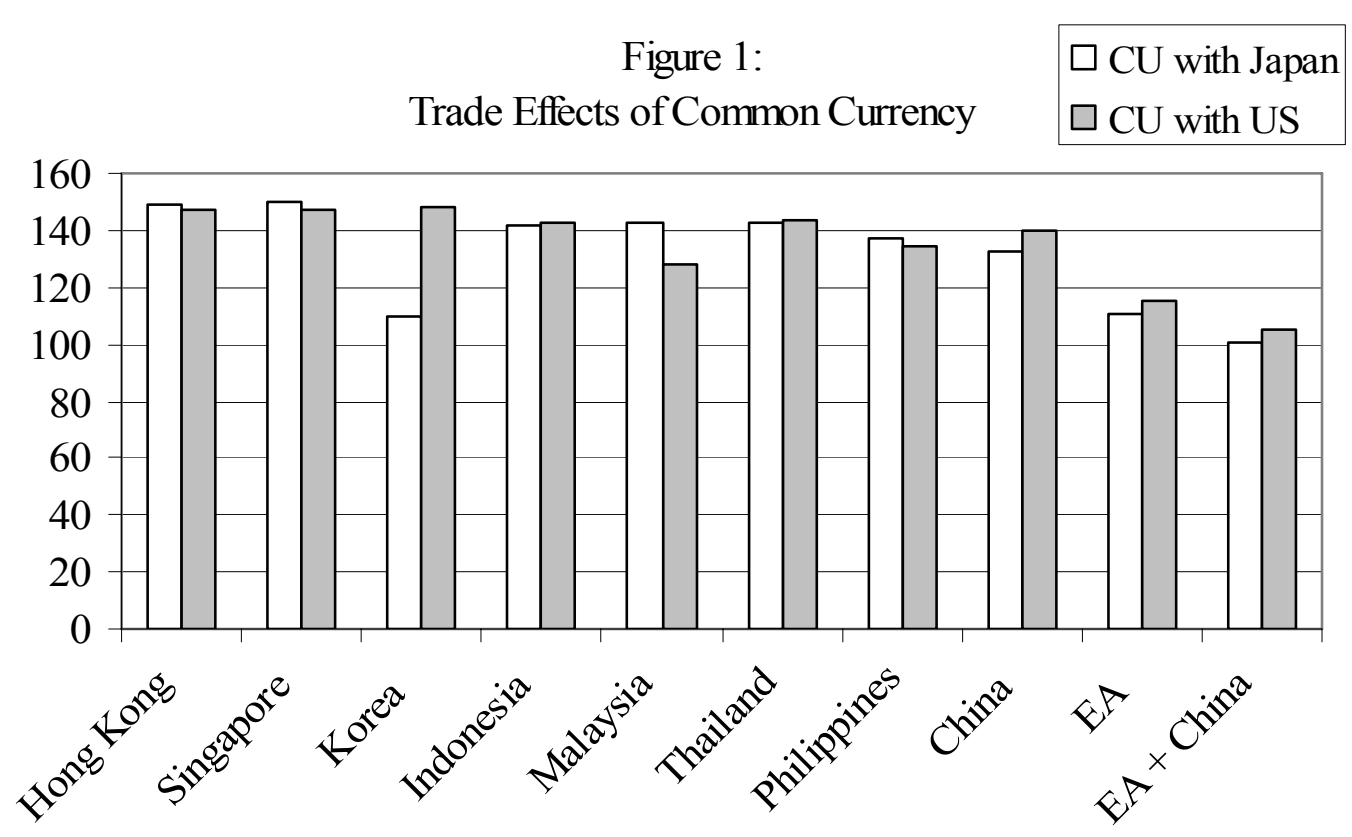

Figure 1 summarizes the trade-creating effects of unilateral currency unions as well as regional currency unions. White bars indicate average percentage increases in bilateral trade under a currency union with Japan. Similarly, colored bars indicate average percentage increase in trade under a currency union with the United States. For example, the first white bar shows the average percentage increase in bilateral trade under a scenario that Hong Kong unilaterally forms a currency union with Japan. Actual estimates and standard errors are reported in Table 5. 
Table 5: Unilateral Arrangements vs. Regional Arrangements

Unit: Percentage

\begin{tabular}{lccccc}
\hline & \multicolumn{2}{c}{ Trade } & & \multicolumn{2}{c}{ Welfare } \\
\cline { 2 - 3 } \cline { 5 - 6 } Hong Kong & CU with Japan & CU with US & & CU with Japan & CU with US \\
\hline \multirow{3}{*}{ Singapore } & 149 & 147 & & 0.2 & 0.4 \\
& $(43)$ & $(42)$ & & $(0.05)$ & $(0.12)$ \\
Korea & 150 & 147 & & 0.1 & 0.3 \\
& $(43)$ & $(42)$ & & $(0.03)$ & $(0.11)$ \\
Indonesia & 110 & 148 & & 4.1 & 0.3 \\
& $(27)$ & $(42)$ & & $(1.21)$ & $(0.08)$ \\
Malaysia & 142 & 143 & & 0.8 & 0.7 \\
& $(40)$ & $(40)$ & & $(0.24)$ & $(0.20)$ \\
Thailand & 143 & 128 & & 0.7 & 2.1 \\
& $(40)$ & $(34)$ & & $(0.22)$ & $(0.68)$ \\
Philippines & 143 & 144 & & 0.7 & 0.6 \\
& $(40)$ & $(41)$ & & $(0.21)$ & $(0.20)$ \\
China & 137 & 134 & & 1.3 & 1.6 \\
& $(37)$ & $(36)$ & & $(0.40)$ & $(0.49)$ \\
EA & 133 & 140 & & 1.7 & 1.0 \\
& $(36)$ & $(39)$ & & $(0.50)$ & $(0.29)$ \\
EA+China & 111 & 115 & & 4.0 & 3.6 \\
& $(27)$ & $(29)$ & & $(1.15)$ & $(1.03)$ \\
& 101 & 105 & & 5.2 & 4.7 \\
& $(24)$ & $(25)$ & & $(1.45)$ & $(1.32)$ \\
\hline
\end{tabular}

Note: Standard errors are in parenthesis.

In Figure 1, the trade-creating effects are large and statistically significant (see Table 5) for all East Asian countries regardless of unilateral arrangements or regional arrangements. The trade effects are somewhat larger for unilateral currency unions, reflecting the small size of such unions. For most part, both unilateral and multilateral currency unions will increase trade flows among member countries by 100 percent or even more on average.

Figure 2 summarizes the results for welfare. As in Figure 1, white (colored) bars in Figure 2 indicate the average percentage increases in welfare under a currency union with Japan (the United States). Figure 2 is contrasting with Figure 1. It demonstrates that regional currency unions will generate much larger welfare increases than unilateral currency unions except for Korea. A currency union between Korea and Japan will increase the welfare by 4.1 percent, which is comparable to the welfare effects of regional currency unions. However, for the rest of the countries, the welfare effects of a unilateral currency union are relatively small or even negligible in some cases. In particular, for some economies such as Hong Kong S.A.R. and Singapore, a regional currency union will generate almost 10-20 times more welfare increases than a unilateral arrangement. Thus Figure 2 confirms the idea that regional 
currency arrangements are more beneficial than bilateral arrangements for East Asian economies, and the benefits of regional cooperation is much larger than those of unilateral policy.

Figure 2:

Welfare Effects of Common Currency

$\square$ CU with Japan $\square$ CU with US

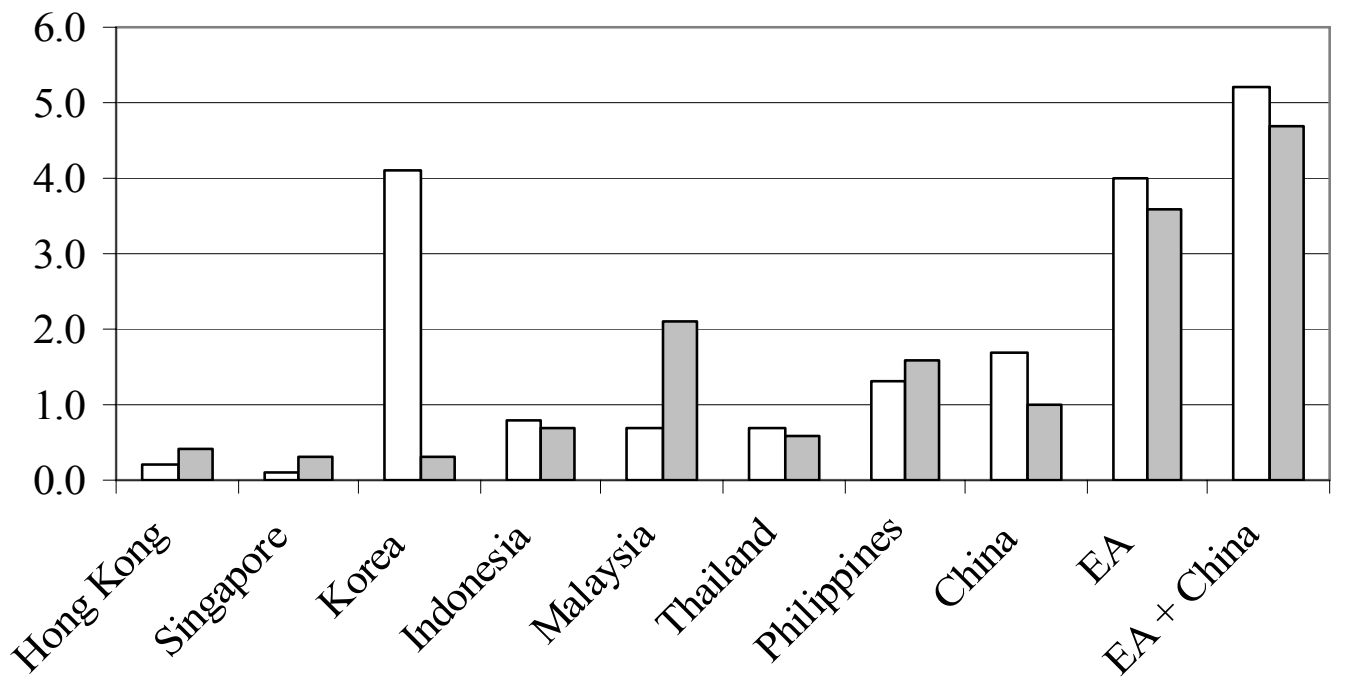

The next task is to compare the trade and welfare effects of currency unions with Japan and those with the United States. Figure 1 shows that unilateral currency unions with Japan and with the United States will have very similar trade-creating effects, around 140 percent, with an exception for the case of Korea. For Korea, the trade-creating effect of a currency union with the United States is 148 percent, somewhat larger than a 110 percent increase in trade from a currency union with Japan. For other countries, the choice of a partner country for a bilateral currency union does not affect the size of the trade effects much because Japan and the United States have very similar shares in their trade.

In Figure 2, as discussed earlier, welfare effects are mostly small for unilateral currency unions regardless of the choice of a union partner, except for Korea. On the other hand, if East Asian countries collectively form a regional currency union with Japan or the United States, average percentage increases in welfare become substantially larger. Moreover, Figure 2 shows that East Asian countries will be better off if they form a regional currency union with Japan rather than with the United States. Including China in the regional union does not affect this pattern. Note, however, that the magnitude of welfare increases from a regional currency union is economically significant but rather moderate. A regional currency union with Japan will increase welfare by around 4 percent, and if China is included, welfare will rise by 5.2 percent. These welfare effects are much smaller than 11 percent of the average percentage increase in welfare for EMU countries, reported by Rose and van Wincoop (2001). 
Nevertheless, the above analysis suggests that a regional arrangement is more beneficial than a unilateral arrangement for East Asian countries, and if East Asia is to form a regional currency union, Japanese membership is more important than American membership because a currency union with Japan will generate larger increases in welfare. This finding can be even strengthened once one takes account of the fact that East Asia was a de facto dollar zone in the sample period of this study: A dollar peg might have facilitated trade between East Asian countries and the United States. In that case, the estimates on welfare effect of a currency union with the United States may be overestimated as the theory suggests that the welfare effect of a currency union is larger the higher the level of pre-union trade.

Japan also plays a more substantial role in the East Asian currency union than other industrialized neighbor countries in the region such as Australia and New Zealand. While a currency union involving only East Asian countries (including China) increases welfare by 3.7 percent on average (Table 3), adding Japan to the union increases welfare by 5.2 percent (Table 5). On the other hand, adding Australia and New Zealand to the union increases welfare by 5 percent (Table 4). Thus the marginal contribution by Japan to the welfare increase is larger than that by Australia and New Zealand combined together.

Some caveats apply to the above results. First, this paper focuses only on the trade aspect of currency unions and benefits associated with changes in trade costs. Thus other potential benefits are not taken into account, and costs of forming a currency union are also not analyzed here. Therefore this paper cannot address a question of the optimality of such a currency arrangement in East Asia. Second, the above analysis cannot address which currency (a regional common currency, Japanese yen, or U.S. dollar) to be used for different currency arrangements in East Asia. More comprehensive analysis will be necessary to incorporate these issues and fully assess the possibility of a common currency in East Asia.

\section{Conclusion}

This paper has investigated trade-creating effects and welfare gains associated with common currency arrangements in East Asia. The estimates suggest that a common currency in East Asia will increase bilateral trade flows in the region substantially. On the other hand, welfare gains are rather moderate particularly for sub-regional currency arrangements that involve only a subset of East Asian economies. However, a region-wide currency union which includes Japan, for example, will generate more substantial welfare gains. As shown in the paper, a regional currency union will stimulate regional trade rigorously, and increased regional trade in turn will facilitate further regional integration in East Asia. As Frankel and Rose (1998) suggest, the more integrated East Asian economies become, the higher the benefits of a common currency may be.

These results suggest that a regional common currency arrangement in East Asia can potentially generate substantial welfare gains. However, in order to secure more significant gains as in the European case, East Asia needs to be integrated further. Recent movements 
toward regional cooperation and integration seem to be a right direction if East Asian economies are to form a currency union in the future. ${ }^{20}$

Lastly, it is important to note that this paper focuses on estimating the benefits of a reduction in trade costs by adopting a single currency. More work needs to be done to quantify other benefits and also the costs of forming a currency union in order to fully evaluate the feasibility of such an arrangement in East Asia.

\footnotetext{
${ }^{20}$ On the other hand, there exists a view that the de fact corporation seen so far in East Asia does not necessarily require a more formalized arrangement of exchange rate coordination. See, for example, Shanmugaratnam (2006).
} 


\section{REFERENCES}

Anderson, James E., and Eric van Wincoop, "Gravity with Gravitas: A Solution to the Border Puzzle," American Economic Review, Vol.93, No.1, 170-192, March 2003.

Anderson, James E., and Eric van Wincoop, "Borders, Trade, and Welfare," Brookings Trade Forum, 207-230, 2001.

ASEAN Secretariat, "Recent Development in ASEAN Economic Integration," Jakarta, September 1999, http://www.aseansec.org/11487.htm.

Benassy-Quere, Agnes, “Optimal Pegs for East Asian Currencies,” Journal of the Japanese and International Economies, 13, 44-60, 1999.

Clark, Peter B., Natalia Tamirisa, and Shang-Jin Wei, with Azim Sadikov and Li Zeng, "A New Look at Exchange Rate Volatility and Trade Flows," IMF Occasional Paper 235, 2004.

Chow, Hwee Kwan, and Yoonbai Kim, “A common currency peg in East Asia? Perspectives from Western Europe,” Journal of Macroeconomics, 25, 331-350, 2003.

Eaton, Jonathan, and Samuel S. Kortum, “ Technology, Geography, and Trade," Econometrica, 70(5), 1741-1779, 2002.

Eichengreen, Barry, and Tamin Bayoumi, "Is Asia an Optimum Currency Area? Can it Become One?" Exchange Rate Policies in Emerging Asian Countries, S. Collignon, J. Pisani-Ferry, and Y. Park, eds., 347-366, 1999.

Frankel, Jeffrey A., "Is Japan Creating a Yen Bloc in East Asia and the Pacific?" Frankel, J., Kahler, M., eds., Regionalism and Rivalry: Japan and the US in Pacific Asia, University of Chicago Press, Chicago, 1993.

Frankel, Jeffrey A., and Andrew K. Rose, "The Endogeneity of the Optimum Currency Area Criteria,” Economic Journal, Vol. 108, No. 449, 1009-1025, July 1998.

Frankel, Jeffrey A., and Shang-Jin Wei, "Yen Bloc or Dollar Bloc? Exchange Rate Policies of East Asian Economies,” Ito, T., Kruger, A.O., eds., Macroeconomic Linkages: Savings, Exchange Rates, and Capital Flows, University of Chicago Press, Chicago, 1994.

Glick, Reuven, and Andrew K. Rose, "Does a Currency Union Affect Trade? The Time Series Evidence,” European Economic Review, 2002.

Hummels, David, “Toward a Geography of Trade Costs," Purdue University, September 2001. 
Ito, Takatoshi, "East Asian Economic Cooperation and Integration: Japan's Perspective," a paper presented in the AEA session on East Asian Economic Cooperation and Integration, January 2004.

Kuroda, Haruhiko, "Transitional Steps in the Road to a Single Currency in East Asia," a statement presented at the seminar on "A Single Currency for East Asia-Lessons from Europe" organized by the Asian Development Bank, May 14, 2004.

Kwan, C. H., "The Theory of Optimum Currency Areas and the Possibility of Forming a Yen Bloc in Asia," Journal of Asian Economics, Vol. 9, No.4, 555-580, 1998.

Lee, Jong-Wha, and Robert J. Barro, "East Asian Currency Union,” October 2006.

McKinnon, Ronald I., “The East Asian Dollar Standard, Life After Death?” Economic Notes, Vol.29, No.1, 31-82, 2000a.

McKinnon, Ronald I., "After the Crisis, the East Asian Dollar Standard Resurrected: An Interpretation of High-Frequency Exchange-Rate Pegging," Stanford University, August 2000b.

Noguer, Marta, and Marc Siscart, "Lost in Translation? An Empirical Investigation of Language Barriers to International Trade," Columbia University, April 3, 2004.

Ogawa, Eiji, and Takatoshi Ito, "On the Desirability of a Regional Basket Currency Arrangement," Journal of the Japanese and International Economies, vol. 16, September, 2002, 317-334.

Ohno, Kenichi, and Kazuko Shirono, "Persistence of the East Asian Dollar Zone," Graduate School of Policy Science, Saitama University, 1997.

Rose, Andrew K., "One Money, One Market: Estimating the Effect of Common Currencies on Trade, Economic Policy, 2000.

Rose, Andrew K., "The Effect of Common Currencies on International Trade: Where Do We Satand?," Occasional Paper No. 22, Monetary Authority of Singapore, August 2002.

Rose, Andrew K., and Eric van Wincoop, "National Money as a Barrier to International Trade: The Real Case for Currency Union," American Economic Review, Vol.91, No.2, 386-390, May 2001.

Shanmugaratnam, Tharman, “Asian Monetary Integration: Will It Ever Happen?,” The Per Jacobsson Lecture, September 17, 2006. 
Williamson, John, "The Case for a Common Basket Peg for East Asian Currencies," Exchange Rate Policies in Emerging Asian Countries, S. Collignon, J, Pisani-Ferry, and Y. Park, eds., 327-343, 1999.

Williamson, John, "Designing a Middle Way between Fixed and Flexible Exchange Rates," a paper presented to a conference on "Monetary and Exchange Rate Policies: Options for Egypt," Cairo, Egypt, November 2000. 